\title{
Performing "digital labor bayanihan": strategies of influence and survival in the platform economy
}

\section{Cheryll Ruth Soriano* \\ Earvin Charles Cabalquinto** Joy Hannah Panaligan*}

\begin{abstract}
Drawing from experience of platform labor in one of the largest labor supplying countries, the Philippines, the paper demonstrates the role of an emerging labor category - that of digital labor influencers - who promote the viability of platform labor locally amid its precarious and ambiguous conditions. Through participant observation in Facebook groups, analysis of YouTube channels and videos, and interviews with digital labor influencers and workers, we present insights into the interventions that these influencers use, anchoring their strategies on what we call performing "digital labor bayanihan": (a) coaching workers on the "possibilities" of the platform economy and on how to navigate its structural ambiguities, (b) by acting as "agencies", they aid workers to span boundaries and fluidly move across platforms and job types to mitigate labor arbitrage and labor seasonality; and (c) bridging geographically dispersed workers, which allow them to form a supportive space where opportunities for labor are exchanged and debated. We argue that these affective strategies attend to Filipino workers' labor aspirations through a community-oriented strategy encapsulated in a distinct Filipino cultural value bayanihan, which then shapes the collective "anchoring" of platform workers to navigate a precarious market. We explore the transactional nature underlying this "producer-audience" relationship, the activation of trust and influence through personalized practices and mediated encounters, and the power dynamic underlying

* De La Salle University, Manila, Philippines.

** Deakin University, Burwood, VIC, Australia.
\end{abstract}


these engagements. The paper shows that these strategies also set norms and standards in this largely unregulated sector, playing a role in how labor mobility or precarity are organized locally amid "planetary labor markets".

Keywords: platform labor, digital labor, crowdwork, intermediation, influencer economy, microcelebrity, Philippines

\section{O "trabalho digital bayanihan": estratégias de influência e sobrevivência na economia de plataformas}

\section{Resumo}

Com base na experiência de trabalho em plataformas de um dos países com maior oferta de mão de obra, as Filipinas, o artigo revela o papel de uma categoria de trabalho emergente - aquela dos influenciadores do trabalho digital - que promove a viabilidade local do trabalho em plataforma em meio a condições precárias e ambíguas. Por meio de observação participante em grupos do Facebook, análise dos canais e vídeos do YouTube e entrevistas com influenciadores e trabalhadores digitais, apresentamos reflexões sobre as intervenções desses influenciadores que ancoram suas estratégias naquilo que chamamos de "trabalho digital bayanihan": (a) oferecendo mentoria (coaching) a trabalhadores sobre as "possibilidades" da economia de plataformas e sobre como conduzir-se em meio a suas ambiguidades estruturais; (b) atuando como "agências" que ajudam os trabalhadores a cruzar fronteiras e a moverem-se com fluidez entre plataformas e tipos de trabalho para mitigar os efeitos da busca pelas empresas de mão de obra mais barata além-fronteiras e da sazonalidade do trabalho; e (c) conectando trabalhadores geograficamente dispersos de modo a criar um espaço de apoio em que oportunidades de trabalho são trocadas e debatidas. Argumentamos que essas estratégias afetivas atendem às aspirações de trabalhadores e trabalhadoras filipinas, por meio de uma estratégia de caráter comunitário encapsulada em um valor cultural tipicamente filipino, o bayanihan, que constrói um suporte coletivo para que os trabalhadores de plataformas possam mover-se um mercado precário. Exploramos a natureza transacional subjacente a essa relação "produtor-público", a ativação da confiança e influência através de práticas personalizadas e encontros mediados, e a dinâmica de poder subjacente a esses relacionamentos. $\mathrm{O}$ artigo mostra que essas estratégias também estabelecem normas e padrões nesse setor em grande parte não regulamentado, impactando a forma como a mobilidade ou a precariedade do trabalho se organizam localmente em meio a "mercados de trabalho globais".

Palavras-chave: trabalho em plataformas, trabalho digital, trabalho coletivo, intermediação, economia dos influenciadores digitais, microcelebridade, Filipinas. 


\section{Introduction}

The increasing networked connectivity and relative affordability of technology facilitated the rise of labor platforms and cloudworking across the world. Platform workers (more commonly called online freelancers locally), mostly located in the Global South, can now directly obtain "gigs" through online labor platforms and microwork intermediaries such as Upwork or Onlinejobs.ph. The Philippines, the site of this study, is one of the largest labor supplying countries in these platforms (Graham; Hjorth; Lehdonvirta, 2017), ranking first globally in terms of growth (Payoneer, 2019). In the advent of abundant information infrastructures and "flexible" work environments, it is assumed that intermediaries will be bypassed in electronic markets as workers can do away with traditional hiring and employment procedures as well as gatekeepers and connect to potential clients directly. Yet, we see an emerging category of digital labor intermediaries - locally called influencers, peer mentors, coaches, and agencies - who are playing a significant role in the expansion and continued uptake of digital platform labor in the country. Building on and drawing connections between earlier works on the influencer economy (see for example Abidin, 2015; Senft, 2013; Marwick, 2013) and the various spaces of labor intermediation, we examine the transactional nature underlying this producer-audience relationship, the activation of trust and influence through personalized practices, solidaristic formations, and mediated encounters, as well as the power dynamics underlying the digitally mediated symbolic practices.

Drawing from a combination of participant observation in online freelancing Facebook groups, an analysis of their strategies on YouTube, and interviews with prominent influencers and digital workers, we present insights into the digital interventions that these brokers engage to wield influence, filling in critical structural gaps by: (a) coaching digital workers on the "possibilities" of the digital labor economy and on how to address the structural ambiguities of digital labor platforms; (b) aiding workers to span digital work boundaries and fluidly move across available platforms and job types to mitigate labor arbitrage; and (c) bridging geographically 
dispersed workers, as well as workers and platforms, in turn allowing them to form a collective space where opportunities for labor are shared, exchanged, and monetized.

The paper seeks to contribute to the digital labor literature in two ways: (i) characterizing the emergence of intermediaries in a labor supplying country, the role they play in planetary labor markets (Graham; Anwar, 2019), and the interventions that they engage; and (ii) analyzing the structural and cultural conditions that facilitate the emergence of digital labor intermediaries who help promote the local uptake of platform labor as well as its implications for labor organization. These points of inquiry allow us to develop and coin the term, "digital labor bayanihan". This conception encapsulates a distinct Filipino cultural value that showcases the collective "anchoring" of digital platform workers in navigating and coping with a precarious digital market through a continuous production of discursive content, networking strategies, and multiple platform engagements. These activities, we argue, are instrumental in fueling an entrepreneurial spirit in the contemporary digital economy. Yet, despite the agency that is demonstrated by online workers through digital labor bayanihan, we also highlight the power dynamics underlying these arrangements and their limitations. We discuss how these connective capacities allow workers to manage ambiguities and challenges posed by platform labor but without challenging the very precarious conditions embedded in its arrangements nor the local structural inequities that make these very conditions palatable for workers.

\section{Platform labor in the Philippines}

Platform labor is celebrated by the Philippine government as a viable solution to unemployment and emerges as a highly attractive work option in the context of poor labor conditions and lack of employment opportunities. The popularity of platform labor is expected to further expand with the covid-19 pandemic, which has resulted in thousands of labor displacements, including among former Filipino migrant workers who were forced to return home. Marketed as a flexible and competitive source of income, 
platform labor has also been attracting workers who experience difficulty in coping with the conditions surrounding older employment models such as business process outsourcing or call center work, or in supplementing casual and unstable employment elsewhere. Yet while workers are able to gain substantial benefits from platform labor, research on digital worker experiences spotlighted its problematic realities, which include increasing levels of anxiety over financial and career instability, limited bargaining capacity, physical stress, and isolation - all of which challenge the overoptimism accorded to digital labor by government and platform promotions (Graham et al., 2017; Lehdonvirta, 2016; Soriano; Cabanes, 2020).

Despite strong government pronouncements promoting digital labor as a crucial solution to unemployment, mechanisms for supporting workers remain limited. Recruitment and employment mechanisms are institutionalized for BPO-related jobs such as call center work (Padios, 2018), while several private and public institutions such as migration agents have been set up to assist workers aspiring to migrate overseas in terms of employment seeking, expectation-setting, salary identification, taxation, or welfare protection (Rodriguez, 2010). By contrast, new entrants to platform labor learn the ropes through taking gigs, often involving direct experiences of scams, client abuse, acceptance of low rates, or frustration over the inability to obtain well-earning gigs from platforms.

Given the tension between the promising opportunities posed by platform labor and the lack of mechanisms to help workers navigate the ambiguous platform environment, a new labor category emerges. These influencers, whom we called "skill-makers" in a previous work (Soriano; Panaligan, 2019), perform the role of "coaches" in various social media platforms and freelancer circles as they usher workers towards aspirations of stable six-digit incomes, gaining loyal foreign clients, and obtaining a sense of self-fulfillment by becoming economically productive while performing nurturing roles at home. Most of them current or former digital platform workers who have achieved considerable level of success, they know the realities and ambiguities of shifting into platform labor, the challenging 
conditions yielded by the platforms' design, and have been exposed to the challenges of working with foreign clients. They capitalize on their experiences and translate these into aspirational narratives and, ultimately, influence.

Expected to be working at home or mobile and physically disconnected, digital workers are often expected to overcome the challenges by themselves and channel entrepreneurial values to thrive in competitive labor markets. This is compounded by the fact that cloudworkers possess different professional identities and take on highly diverse jobs with varying levels of engagement that can impede in collective formation. This aligns with social capital theorists' concern that a sense of community of workers is declining with the fragmentation of workplaces and internationalization of global value chains driven by technological development (Neilson; Rossiter, 2008). Nonetheless, as we will show, workers engage in unique formations (Soriano; Cabanes, 2020; Wood et al., 2018) - albeit in ways that depart from traditional forms such as unionizing - through the facilitation of these influencers that allow them to circulate and share strategies of survival. Amid the opportunity and precarity underscored by the neoliberal economy and shortcomings in state interventions for advancing the local labor condition, digital labor influencers emerge with bridging, coaching, and boundary-spanning strategies, playing a crucial role in shaping the digital labor regime locally.

\section{Digital labor influencers, social media, and bayanihan}

Practices in the digital labor economy are enacted in a participatory and convergent culture where ordinary individuals produce, curate, circulate, and consume content. For instance, individuals use blogs and other online channels to present the often personalized, localized, and vernacular contents (Hjorth, 2011; Burgess; Green, 2018) related to labor opportunity or precarity. The multiple affordances of different online channels have paved the way for various connective capacities of individual users. The production and circulation of content, which generate social interactions, 
has produced online figures, such as microcelebrities. Senft (2013) defines a microcelebrity as someone who utilizes digital communication technologies for online interactions and capitalizes on these interactions to develop, amplify and sustain popularity among networks. Marwick (2013) has further expanded on the conception of a microcelebrity by highlighting diverse "branding strategies" of individuals who utilize online or web technologies to develop networks and start their own business. For Marwick (2013), branding strategies often involve emotional and affective labor, reflected in how authenticity is worked upon based on the demands of their networks. Meanwhile, Abidin $(2015,2018)$ advances the discussion on microcelebrity branding strategies by unpacking different communicative tactics used by these content creators who become "influencers". Abidin highlights four dimensions of such practices, including commercial, interactive, reciprocal, and disclosive strategies. Individuals work around calibrating an amateur, raw, and spontaneous content while also sustaining relationships with networks and audiences through online and offline engagements (Abidin, 2015; 2018). In turn, they are able to capitalize on their content, networks, and practices for monetization. In the global South context, it is crucial to examine the work of these influencers in terms of articulating and shaping the aspirations of multiple audiences.

The rise in the popularity of platform labor in the Philippines is accompanied by the rise of digital labor influencers. The work of influencers in the world of work had been previously analyzed in critical research concerning "pop management" literature (Wood; De Paula, 2008; De Paula; Wood, 2009). These studies examined the actions and narratives of "management gurus" who arose as opinion makers in organizational and labor management through strategically crafted expositions that attract mass appeal (Duarte; Medeiros, 2019). For example, they advance "fantasy themes" (Wood; De Paula, 2008) including the promotion of the aspirational imperative of achieving a "position of command" or authority as a source of power (De Paula; Wood, 2009). At the same time, they are seen to privilege the market view and reproduce ideologies that defend managerial interests 
through the "creation and use of success stories, the celebration of heroes and winners in change processes, and the popularization of the clichés" that can obtain wide social acceptance (De Paula; Wood, 2009, p. 602). This genre of literature is importantly characterized by "self-help", a style that draws from the promotion of self-knowledge and entrepreneurialism to overcome problems in management and work (Duarte; Medeiros, 2019). Instead of creating influence through a position of authority as with traditional bureaucratic controls, the control that they wield is underscored by the capacity to elicit feelings of relatability to the ideas that they promote, especially as these are often positively and internally framed and not requiring the challenging of broader structures.

Platform labor influencers appropriate branding strategies to position themselves in the digital labor market, craft networking and communitybuilding activities in a hybrid online or offline space, while advancing "selfhelp" strategies amid the promotion of online freelancing as a viable and attractive work opportunity. In a sense, platform labor, "pop management", and micro-influencer work align - they promote an entrepreneurial self that can embody resilience, passion, and hard work needed to survive in a neoliberal economy (Marwick, 2013; Gill; Pratt, 2008). Perhaps one key push for the crystallization of labor influencers' emergent role in the digital platform labor market is their capacity to capitalize on social media affordances of visibility and networked connectedness that enables them to quickly publish content and gain traction and sustained engagement, while promoting the same pop management ideas of self-help and power fantasies.

Emerging digital labor influencers appropriate microcelebrity strategies enacted through the facilitation of a distinct cultural value, which we refer to as bayanihan (helping each other in a time of crisis). We utilize this conception as we examine the branding strategies of Filipino digital workers who are embedded in a digital and neoliberal economy. Bayanihan is a community-based practice in the Philippines, originally conceptualized in the context wherein the entire community helps to move the house of a community member. With the Filipino value of hiya (shame) and utang na 
loob (indebtedness) (Pe-Pua; Protacio-Marcelino, 2000), the person who owns the house expresses gratitude by rewarding the people who participate in bayanihan by feeding them with snacks. On the other hand, people invest in bayanihan if there is trust and prospects of short or long-term benefits that can result in communal and potential long-term relationships (Pe-Pua; Protacio-Marcelino, 2000). In the contemporary context, bayanihan emerges in times of crisis, such as relief and post-disaster recovery contexts (Eadie, 2019), when individuals form collectives and support networks in relief and rehabilitation activities.

Community ties and affinities are socio-historically situated. In the first instance, the word bayan from the word bayanihan refers to a town or community, and not necessarily to the nation-state. San Juan (2001, p. 255) argues that the "Filipino identification is not with a fully defined nation but with regions, localities, and communities of languages and traditions". He further explains that such affinity is a result of the Filipinos' perception of the state as a corrupt exploiter and an ally of transnational corporations and Western systems. Significantly, connections in communities can be driven by affective experiences of the majority and ordinary Filipinos who lack access to basic social welfare services and job opportunities (Aguilar, 2014). For instance, overseas Filipino workers support each other in their host countries through "fictive familial relations" and networking (FranciscoMenchavez, 2018). For this paper, bonding and support emerge among freelance digital platform workers through the intermediation of influencers. In a way, the economic and political landscape contributes to bayanihan that is extended in the digital and marketized sphere, showcasing how workers support each other by exchanging tips on digital work, networking, and community building.

As we will show in the succeeding sections, emerging digital labor influencers, as if facilitating digital labor bayanihan, create opportunities for workers to recognize a sense of "community" among them, and to come together where support and strategies for survival in the platform 
economy are actively exchanged and also visibilized, thereby sustaining itself. Through coaching, boundary spanning, and bridging strategies, digital workers gravitate towards each other in response to the ongoing crisis of job precarity in the Philippines. Online relationships are sustained by both networking and circulation of content - facilitated by influencers who showcase pathways to and prescriptions for success.

Yet, power asymmetries also emerge in the process and although bayanihan is generally understood as an altruistic cultural practice, these solidarities can be undermined when uneven power relations persist (Eadie, 2019). In the same way, the work of influencers, although facilitating the sharing of support strategies crucial to help workers survive this pernicious labor market, can embody asymmetries in terms of benefit and power.

As such, we propose the term digital labor bayanihan as encapsulating a Filipino cultural value that shapes the collective "anchoring" of digital platform workers to survive a precarious digital market. Although this "concept" emerges from the Philippine context, the ideas may be relatable to or extended in contexts where sources of collective imaginaries are comparable. Finally, as we will show in the succeeding sections, its application in this paper characterizes the dynamic and mutually reinforcing influences of the global and the local in the platform economy.

\section{Methodology}

This study draws from over four years of online participant observation in digital labor Facebook groups and interviews with forty-one prominent digital platform labor coaches and freelance workers. Face to face and online interviews were conducted from January 2017 to December 2019, and participants were recruited through meetups in freelancer events and through snowballing thereafter. Observations during these events as well as initial interviews were important in constructing background information about the online freelancing scene in the country and provided clues on 
the role of online spaces for platform workers and which ones to observe. We noted the names of prominent coaches identified by the workers as playing key roles in promoting online freelancing, some of whom were also interviewed for the study. For those who gave us their consent, we then followed and examined the Facebook groups they moderated (refer to Table 1), paying attention to engagement styles and communicative tactics.

Over the course of the study, we noticed the importance of YouTube, where video content on navigating platform labor is actively created, discussed, and shared with other platforms. This prodded us to analyze the top seven Filipino digital labor influencers on YouTube and whose channels have a range of 22 thousand to 300 thousand subscribers, some with total channel views of over 20 million. Although some have fewer subscribers than others, their videos gained 20 thousand to close to one million views each, indicating that their sway as online freelancing influencers is substantial. We then conducted a textual analysis of sample YouTube videos of these digital labor influencers (refer to Table 2), examining their narrative and engagement styles.

Table 1. Facebook groups analyzed

\begin{tabular}{llc}
\hline $\begin{array}{c}\text { Facebook } \\
\text { Community/ } \\
\text { Group Name }\end{array}$ & \multicolumn{1}{c}{ URL } & $\begin{array}{c}\text { No of members } \\
\text { as of Sept } 2020\end{array}$ \\
\hline $\begin{array}{l}\text { Online Filipino } \\
\text { Freelancers }\end{array}$ & $\begin{array}{l}\text { https://www.facebook.com/groups/ } \\
\text { ElanceOdeskFreelancersPH }\end{array}$ & 237,000 members \\
\hline $\begin{array}{l}\text { Freelancers in } \\
\text { the Philippines }\end{array}$ & https://www.facebook.com/groups/flipph & 186,200 members \\
\hline $\begin{array}{l}\text { Freelance Blend } \\
\text { Freelance }\end{array}$ & https://www.facebook.com/groups/freelanceblenders & 1,000 members \\
\hline $\begin{array}{l}\text { Philippines } \\
\text { Pinoy Dads }\end{array}$ & https://www.facebook.com/groups/freelancing.ph & 19,200 members \\
\hline $\begin{array}{l}\text { Social Media All } \\
\text { Stars }\end{array}$ & https://www.facebook.com/groups/smmph & 13,100 members \\
\hline
\end{tabular}


Table 2. YouTube videos analyzed

\begin{tabular}{|c|c|c|c|c|c|c|}
\hline $\begin{array}{l}\text { Digital } \\
\text { labor } \\
\text { influencer }\end{array}$ & $\begin{array}{l}\text { Date of } \\
\text { joining } \\
\text { Youtube }\end{array}$ & Subscribers & $\begin{array}{l}\text { Total no. } \\
\text { of videos } \\
\text { in channel }\end{array}$ & $\begin{array}{l}\text { Title of video } \\
\text { analyzed }\end{array}$ & $\begin{array}{c}\text { Date } \\
\text { published }\end{array}$ & $\begin{array}{l}\text { Video } \\
\text { Views }\end{array}$ \\
\hline $\begin{array}{l}\text { James } \\
\text { Tristan } \\
\text { Ruiz }\end{array}$ & 04/06/2017 & 391,000 & 142 & $\begin{array}{l}\text { Online Jobs at } \\
\text { Home Philippines } \\
\text { For Beginners (Full } \\
\text { Tutorial) }\end{array}$ & $\begin{array}{l}\text { Nov 26, } \\
2019\end{array}$ & 254,000 \\
\hline $\begin{array}{l}\text { Edille } \\
\text { Rosario }\end{array}$ & $18 / 04 / 2019$ & 45,500 & 90 & $\begin{array}{l}\text { Top } 3 \text { Best Freelance } \\
\text { Websites Philippines }\end{array}$ & $\begin{array}{l}\text { May 21, } \\
2019\end{array}$ & 10,000 \\
\hline $\begin{array}{l}\text { Demi } \\
\text { Bernice }\end{array}$ & 09/06/2015 & 4,450 & 93 & $\begin{array}{l}\text { How to Earn } \\
\text { P118,600 Per Month } \\
\text { on Freelancing in the } \\
\text { Philippines: Monthly } \\
\text { Income Report May } \\
2019\end{array}$ & $\begin{array}{l}\text { June 07, } \\
2019\end{array}$ & 11,000 \\
\hline $\begin{array}{l}\text { Mimi } \\
\text { Luarca }\end{array}$ & $14 / 11 / 2011$ & 125,000 & 79 & $\begin{array}{l}\text { Be a Part-time } \\
\text { Transcriptionist } \\
\text { in REV and Earn } \\
11,000 \text { pesos! Work } \\
\text { from Home English } \\
\text { Subtitles }\end{array}$ & $\begin{array}{l}\text { October } \\
21,2019\end{array}$ & 288,000 \\
\hline $\begin{array}{l}\text { Jhazel de } \\
\text { Vera }\end{array}$ & $30 / 06 / 2015$ & 114,000 & 234 & $\begin{array}{l}\text { EARN UPTO } \$ 500 \\
\text { / MONTH BY } \\
\text { VIEWING IMAGES } \\
\text { / Hashingadspace. } \\
\text { com Review }\end{array}$ & $\begin{array}{l}\text { Aug 13, } \\
2019\end{array}$ & 464,000 \\
\hline $\begin{array}{l}\text { Ernaldo } \\
\text { Vlogs }\end{array}$ & 09/01/2013 & 47,900 & 28 & $\begin{array}{l}\text { PAANO KUMITA SA } \\
\text { FACEBOOK? (How } \\
\text { to earn on Facebook) } \\
\text { Ad Breaks (In-Stream } \\
\text { Ads) Tutorial T }\end{array}$ & $\begin{array}{l}\text { July 23, } \\
2019\end{array}$ & 780,000 \\
\hline $\begin{array}{l}\text { Sheena } \\
\text { Santos }\end{array}$ & 04/10/2011 & 9,640 & 119 & $\begin{array}{l}\text { How To Make } \\
\text { Money On Fiverr } \\
\text { Without Skills - How } \\
\text { To Make Money On } \\
\text { Fiverr For Beginners } \\
\text { (2020) }\end{array}$ & $\begin{array}{l}\text { Aug 12, } \\
2019\end{array}$ & 111,000 \\
\hline
\end{tabular}




\section{Performing "digital labor bayanihan": coaching, boundary spanning, and bridging workers amid platform labor ambiguity}

\section{Social media and digital labor influencers}

Digital labor coaches initially attract a following through face-to-face coaching sessions beginning with a small pool of aspiring freelancers. As they get known in the industry, these coaches would be invited to speak during online freelancing events which allows them to develop a network of trainees with which they build their Facebook groups. The groups we examined all have thousands of members. Although some Filipino online freelancing Facebook groups are clustered in terms of job (i.e. Virtual Assistants of the Philippines), platforms (i.e. Upwork Philippines) or by regional clusters (i.e. Freelancers of Cebu), these Facebook groups organized and moderated by influencers have members that cut across jobs, platforms that they use, and geographic location. A few of the members are Filipinos based overseas who are involved in platform labor. The main connective node for these members is the influencer, whether by having been coached directly by him or her, or by having been referred by a mentee to join the group.

YouTube influencers covered by the study were mostly in their early 20s to middle-aged professionals of mixed gender (at least in their selfpresentation or persona) who maintained channels with regularly uploaded videos, and many of them have versions of their channels on Facebook. Most of their YouTube content followed the self-tutorial format and other "self-branding" strategies such as sharing personal experience, highlighting strategies for overcoming online freelancing challenges, and using video branding styles in the opening and closing credits of their videos. They also promote the benefits of working from home by sharing their freelancing journey, including tips to thrive. The notion of self-branding implies that microcelebrities need to differentiate themselves from the rest by creating 
a persona, or role that they project in the content or product they make, and eventually facilitate influence over people (Abidin, 2015; 2018). They also specialize in selling an "expertise", either on the basis of a particular skill (i.e. digital marketing) or mastery of a platform (i.e. Upwork or Rev) that they would like to be associated with. Consistent with the work of microcelebrities, visual and audio styles of self-branding include the use of the color scheme, font, layout, or music bed, which are consistently held across the videos of each influencer (Marwick, 2013; Abidin, 2015; Senft, 2013). This creation of a "persona" (i.e., representing 'mom' freelancers) illustrates how influence involves the marketing of personal sensations to attract and sustain an audience, while at the same time differentiating one's "goods" from the rest.

We generated the following key themes that outline these actors' key emerging roles in platform labor: (i) coaching, (ii) boundary spanning, and (iii) bridging. These are anchored on performing a "digital labor bayanihan", an appropriation of a Filipino cultural construct of solidarity.

\section{Coaching}

For workers and especially for new entrants, platform labor is confusing and the fully mediated form of labor engagement implies that workers need to navigate it without much formal guidance from any institutional authority. These ambiguities include discerning legitimate platforms and clients, building a compelling digital portfolio, figuring out how to bid for a job, how to perform a job online, or how to manage a foreign client and their demands. Strategic pricing is also a common source of ambiguity given the nature of bidding for jobs embedded in platform design. For those transitioning from full-time physical employment to platform labor, workers express concern about the seasonality of work or whether there are mechanisms for negotiation if clients end up unwilling to pay for completed tasks (Soriano; Panaligan, 2019). Importantly, many aspiring workers do not possess college degrees nor direct training to perform the tasks offered 
in platform labor. Clinging on to the promises of platform labor, they try to "learn" these on the go through watching YouTube videos and joining Facebook communities organized by influencers.

Coaches act as authority figures who guide digital workers in navigating their way around digital labor's precarious and ambiguous working conditions. Posts shared in these Facebook groups and on YouTube range from "how to begin as an online freelancer", "how to sell one's skills", coaching on specific skills (i.e. website development, social media management, web design, or virtual assistance), or advise on how to invest their earnings. Snippets of these training sessions are shared for free but some of the materials are packaged as paid training programs. On YouTube, posts would include live interviews featuring guest speakers to demonstrate successes in online freelancing. Another primary content on their YouTube videos is about financial sustainability, coaching workers on how to price one's skills, how to increase income streams, and how to invest their earnings given the looming seasonality of work that many freelance workers are concerned about. Their position as "experts" reflects a semblance of organizational hierarchy often seen in traditional work setups. However, it differs when it comes to their approach as they often use the persona of being an ordinary online worker, often using the term, "we," "us freelancers" or "one of you". Coaching is not straightforward and these influencers employ a range of communicative strategies that also allow them to tap into social media's multiple affordances to facilitate greater traction and engagement.

Highlighting personal narratives is affective because this can boost attention and craft a notion of authenticity and relatability for their audiences (Abidin, 2015). Echoing notions of "self-help", characteristic of pop management literature that we discussed earlier, the idea that they started as an ordinary digital worker and worked their way up by employing the same methods that they coach is an important feature of their strategies. The recognition of the coach's "personal story of success" is a demonstration of aspiration and of the possibility that, through the use of such strategies, 
one can overcome the difficulties of platform labor. Many of their followers express gratitude for these "free tips" and, in turn, influencers actively acknowledge their subscribers or fans in the form of "shoutouts".

To demonstrate their expertise while sharing nuggets of their success, they offer giveaways to mark their online career milestones, such as reaching 300,000 subscribers or gaining six-digit incomes. These online draws or livestream giveaways can be a personal endeavor or a sponsorship tie-up with an industry partner or store related to freelancing. The giveaways can be in the form of monetary cash sponsored by a bank or financial payment partner to encourage freelancers to use their online platform or a free laptop sponsored by a computer store. The mechanics they share are often related to subscribing to their social media accounts and engaging with their content. Although they promote it to give back and celebrate their milestone, it serves a dual purpose as they can gain more followers and in turn monetize these engagements. It illustrates how responsiveness and reciprocity validate their position and they use their influence over the online freelance community to monetize this labor. Labor influencers offer tips through engaging questions that attract more viewers or subscribers:

if you want me to make a video of what my work is like as a Youtube channel manager or expert, click the like button, and, if this video reaches 5,000 likes ka-homemates, I will make a video about my job and what you need to learn. Thank you for watching, Ka-homemates [fellow-homemates]. Make sure to click the like button if you liked this video. Share this to your friends if they want to learn how to work at home (Ruiz, 2019).

In the process of coaching, labor influencers also cascade imaginaries of success to their audiences. The influencers often highlight aspirational labor (Duffy, 2017), which focuses on the promise of a reward in the future that one can reap through current productive activities. These imaginaries of success can be seen as a modern form of "coaching" manifested through self-branding techniques such as repetition styles and sharing of personal narratives. The construction of value standards pertains to setting norms of 
what counts as "success", what counts as a "good client," what constitutes a "good digital worker," a "good project," or even a "conducive workspace". For online freelancer couples, there are also posts about how they can effectively work from home while maintaining a "happy family life".

The coaches do not only showcase their own success stories, they also highlight others' successes, often of those mentored by them. In one example, a coach hosts a Facebook live featuring a former mentee who has "successfully shifted from being a factory worker to becoming a virtual assistant". The live interview tells the story of how the guest, without having completed a college degree, has managed to leave her full-time factory work, command high rates and obtain a sustained pool of clients, again while enjoying a good, flexible work-life. In another live interview, an influencer highlights the experience of a former overseas Filipino worker who returned to the country permanently after a series of successful gigs as a platform worker. Showcasing this experience allows the coach to demonstrate social proof of the effectiveness of his or her capacity to mentor - and having this conveyed by others (i.e., mentees who have religiously applied the coach's lessons to reach the path to success) lends it more believability. An influencer explains why this "social proof" is valuable:

well, the stigma is that when you see people talking about earning online, it is a scam. That's also what I used to think before and the stories of legitimacy of freelancing kinda counteracts it so the more real people that we see who are actually earning online and actually earning as freelancers, that helps break that stigma. So, you can see online - you know, somebody who actually does work online and become successful - that gives more social proof to freelancing. (JD, male, founder of a Facebook group for online Filipino freelancers, personal communication, 1 August 2017)

As helpful as these sharing of personal strategies could be, the narratives downplay the challenges that workers experience, although some of the workers would occasionally share their gripes about platforms or clients in these spaces too. In response, the coaches would often emphasize the 
importance of hard work, resilience, and that digital labor "success" can be achieved with the "right frame of mind," as well as "grit and guts". It is important to emphasize that, over time, other members of these groups are observed to take on the role of coaches for one another, and this is done by posting their own "winning strategies", or visual images of what they have achieved, again presenting an image of possibility, but also their own version of success that aspiring freelancers can emulate.

\section{Boundary-spanning}

Boundary-spanning is another prominent feature of local strategies for coping with the precariousness of platform labor, and which is enacted by these influencers who also become "agencies". We discuss boundaryspanning in two ways: (i) where workers span the boundary between being a worker and an agency; and (ii) when influencers who are also workeragencies coach workers to diversify and span projects and platforms.

\section{SPANNING BOUNDARIES FROM WORKER TO "AGENCY"}

Workers who manage to acquire large projects become whom freelancers more popularly call "agencies" (or "freelance start-ups") that outsource projects or segments of their projects to other workers, including family members or neighbors (Soriano, 2021). Idealized and accorded high esteem by many of the workers interviewed for this study, these agencies are not only able to command high rates and larger projects, but also generate significant social and financial capital from the clout that they build around their local community of recruits, as well as from the trust gained from clients for running larger projects. Workers hold these agencies as their measure of "success". Agencies explain that a worker can secure this agency position by being able to strategically develop one's portfolio and having an entrepreneurial mindset, that is, an important shift from "thinking like a worker" to "thinking like an entrepreneur". The agency arrangement is 
one that can be performed by workers informally on their own, or under the labor platform's agency structure (see Upwork, for example). Workeragencies who have managed to retain a stable pool of "loyal" clients and large projects also receive some sort of protection from the blows of labor seasonality. As workers take on larger projects with long-term clients, not only does their overall rate increase; the percentage rate of what they pay the platform can be lower (Soriano, 2021). This also puts them in a better capacity at negotiating additional cash and non-cash benefits with clients.

Many of the influencers who are worker-agencies that we encountered in our fieldwork outsource large projects to their personal network of friends and family informally. When covid-19 struck, some of these influencers who also run their own agencies were observed to highlight posts recruiting workers who have lost their direct clients and absorbing them in their own agencies. Through this process, they are able to gain more clout and influence due to their ability to fulfill a direct need for an income source in the time of crisis. Thus, beyond coaching, they offer freelancer actual jobs. In turn, their posts also invite other freelancers who manage to gain larger work portfolios to do the same, posting opportunities to hire Filipino workers for re-outsourced jobs. It is beyond the limits of this paper to ascertain whether this sub-contracting process results in fair pay and good working conditions for the workers that they hire. As freelance workers who have experienced the digital labor's precarious conditions, it would be reasonable to expect that this process would be mutually beneficial to the influencer as well as the subcontractors, although abuse and power asymmetries are certainly possible. This would be an interesting theme for further exploration.

JOB, CLIENT, AND PLATFORM SPANNING

The other strategy that influencers preach is that online workers diversify and span jobs and clients, and the influencers and worker-agencies help them be able to do this. This is an important strategy to assuage labor arbitrage, a strategy where foreign clients select the cheapest labor available from a large 
pool of aspirants (Wood et al., 2018). Practicing what they preach, these influencers, due to the substantial clout that they have gained, can span projects and jobs and these projects are then cascaded to other workers. This allows them to demonstrate why diversifying skills and projects is crucial in the online freelancing environment. Secondly, the influencers coach their teams to diversify platforms. They would advise the workers that when they enlist themselves in multiple platforms, they get substantial leverage because they are not tied to the conditions imposed by a single platform. In their communities, other workers chime in, sharing their experience with specific platforms and suggesting alternatives as well as the benefits of platform and job diversification. As an influencer explains:

I do have a video and what I state there it's not any less stable than a traditional job.... And with freelancing you can put your eggs in multiple baskets so you can have multiple clients and platforms you can work with at the same time and that you can work for you so if one company goes out of the business or if you get fired from one client you can always have another client you can work with. You have multiple clients so that's how you can work with stability. (JD, male, founder of a Facebook group for Filipino online workers/ freelancers, August 01, 2017)

As they confidently move from one platform and client to another, they gain a range of clients who sometimes choose to transact with them outside the platform. Some of them also gain a more entrepreneurial mindset as they take on large projects.

\section{Bridging}

Networked connectivity plays a huge role in enabling encounters and interactions among individual users in a particular platform, which facilitate the formation of connective ties leading to "online community" formations. Baym (2010) identifies the five dimensions of an online community, including a sense of space, shared practice, shared resources or capital, shared identities, and interpersonal relationships. In the context of YouTube, amateur 
producers contribute to community building by exchanging information, creating spaces to recognize commonality in experience, and facilitating circuits of collective help and support (Burgess; Green, 2018; Lange, 2019). This means that individual users connect to each other in both online and offline spaces, bound by sociality, relatability on affective experiences, and support mechanisms.

In this study, we refer to bridging as a process enacted by digital labor workers in serving as a connector: (i) between them and their followers/ subscribers; (ii) between workers; (iii) between potential clients and aspiring workers; (iv) between workers and platforms; and (v) between workers and their digital labor aspirations. These individuals often employ personalized, authentic and relatable content as a form of strategic branding (Marwick, 2013), which harnesses and sustains online interactions. Crucial in this bridging work is the framing of success stories as attainable through dedication and hard work. Personalized narratives of self-help, which follow previous practices of curatorial practices on blogs (Hjorth, 2011), and pop management literature (De Paula; Wood, 2009; Wood; De Paula, 2008) serve as a focal point for imaginaries of entry in the gig economy or for upward mobility. However, while narratives highlight their personal journey, these also articulate the presence of help and support from the community. This is communicated by inviting aspiring digital workers to subscribe, engage with the videos, interact with other followers, and share their own experience. Personalized narratives are reflections of unique branding strategies to maintain connections and sustain monetization (GarciaRapp, 2017). Such practice is not only strategic for the digital worker to gain followers and monetize content via hits and views. It is also a distinct characteristic of "digital labour bayanihan" wherein an individual is offering support by sharing stories, strategies, and pathways to success while at the same time instigating others to do the same. This shows then that a sense of community is operationalized by forming a space for a sustained exchange of ideas, support, and even wielding aspirations. 
All our influencer informants emphasized the importance of online communities to maintain their network of workers and grow their number. Moreover, the influencers also recognize that building a community is the fastest way to grow one's brand organically because it allows the audience to join in the conversation and share content. Notably, a bigger community also equates to higher monetary income. The activation of an imagined community of online freelancers is a crucial feature of their strategy. Through the use of "terms of collective endearment", such as addressing their audiences as "Kahomemates" a Filipino colloquial term known as an "online colleague", or "Ka-OFF (fellow Online Filipino Freelancer)" they create a sense of common identity for workers who perform different jobs, who may have never met, and who are geographically distant. Working online can be isolating, and terms such as "Ka-homemates" help bridge the gap and resemble the experience of social learning from a colleague. A sense of community is a valued commodity in online freelancing because it employs an affective bond to foster a connection with their followers amid varied professional identities, levels of experience, and physical distance. This community is used as an anchor to help them survive the platform economy's precarious labor conditions. As illustrated by one of the influencers:

It's very important for freelancing to build a community to which they belong, even if it is virtual, and you can only see them online, you still get to be with them. [...] So if you are new, no one gets to help you. It's very easy to be scammed, so that is why platforms and community are really important so we can also guide the newbies [...] (CC, female, Founder of a Facebook group for online Filipino freelancers, personal communication, 13 February 2018)

Invested with the expectation of future returns, influencers establish communities with which they offer a diverse range of coaching resources that allow them to build reputation and trust, as well as activate their boundary-spanning strategies. In turn, workers establish skills and social capital by being attached to the influencer and gaining a community of support crucial in an ambiguous labor environment. The influencer then 
is able to monetize the value of helping workers navigate the ambiguity of the digital platform environment, while workers continually see the need for them due to the perceived value that they can offer:

If you have one thousand true fans, who are willing to pay you a hundred dollars a year. You already have a business, and you are already set for life. Having 1000 "true fans" basically means that you have power, over a thousand people, who would support what you do, buy your stuff, who would open doors for you, help you and give you new opportunities. Although not all of the people that follow you are $100 \%$ true fans. You still have people who will listen to your ideas daily. You can give value by sharing your ideas, and even if they are not your customer, that person might know someone, and it can lead you to have more opportunities for you. (NE, male, founder of a Facebook group for online Filipino freelancers, 26 January 2018)

Crucially, as key movers who promote the viability of platform labor through these bridging strategies, they not only bridge workers with them and with each other, they essentially function as bridges between workers and digital platforms, as well as with clients.

\section{Conclusion}

The paper examines the conditions that give rise to digital labor influencers, their role in the platform economy, and how through their communicative strategies they also set norms and standards in this largely unregulated sector, leading to fostering trust among their followers and enabling them to benefit economically and socially in the process. In turn, we also considered how labor mobility or precarity is organized through the work of these actors. We argue that digital labor influencers, through coaching, boundary-spanning and bridging strategies, play a symbolic role in mediating the relationship between the local digital labor workforce and digital labor platforms.

Social media channels play a critical role in the production and circulation of personalized content, while the aesthetics, narratives, and 
discursive styles of these influencers convey aspirations of economic mobility for their community members and aspiring online platform workers. This interaction between platforms, influencers, and their followers engenders social support and networking opportunities needed to thrive in the platform economy. Further, influencers build on their branding strategies by visibilizing their experiences, struggles, and success, which is crucial in attracting viewers to imagine, desire, and enact alternative pathways for survival. Instead of feeling defeated, Filipino digital workers have exhibited their own ways of working around the situation while also benefiting from certain functions of these social media clusters. Evidently, this mirrors the value of affect in which workers in the face of precarity grow capable of developing innovative new ways to promote solidarity and solve common struggles (Gill; Pratt, 2008). Stories of success, tactics in navigating a new digital market, and thriving in a gig economy become essential and immaterial goods that support individuals with shared experience in the struggle to actualize their aspirations within a precarious environment.

The study sheds light on the often-unseen ways by which planetary labor markets are organized locally. We showed how, through the work of these influencers, a sense of digital labor bayanihan is enacted and appropriated through strategies that are deeply inscribed within a particular Filipino sense of collectivity and solidaristic spirit performed when State and other structures of support are limited. By highlighting strategies of bridging, coaching, and boundary-spanning, we showed how platform workers' dynamic negotiation of agency enables workers to seek some relief from the structural constraints and precariousness of platform labor while allowing them to envision or partially (or fully) achieve their aspirations. In turn, influencers obtain patronage capital by becoming industry leaders. Yet, while the more enterprising followers are able to emulate them, others continually cling to the celebratory promises of platform labor and valorize them. The performance of "digital labor bayanihan" helps visualize these aspirations, make the influencing work attractive, and draws workers to 
this economy while concealing the politics and asymmetries embedded in these strategies. At the surface, workers' comments in these communities are generally of gratitude and solidarity, although a systematic analysis of the engagement by workers can be the subject of future studies.

Looking beyond the limits of the long-standing dichotomy of empowerment and disempowerment, digital labor influencers present the duality and also the complexity of influence, intermediation, and survival in the platform economy. While they play a crucial role in helping workers make sense of platform labor when they have no better alternatives nor access to similar forms of dynamic guidance elsewhere, they also cascade imaginaries that workers hang on to, as these nurture their economic and social aspirations, whether these latter are realized or not. It is in the heart of such contradictions that platform workers imagine new forms of sociability, visions of happiness, and economic capacities, despite uncertainty on whether these can in fact be actualized (de Peuter et al., 2017). This implies that they also perform the role not only of bridging workers with each other, but bridging workers with platforms, essentially performing unpaid labor for digital platforms. It follows that they also serve as promoters of the Philippine government's vision of promoting Filipinos as "world class workers" while allowing it (along with digital platforms) to avoid its responsibility to attend to the deeper structures of labor inequality.

Cherryl Ruth Soriano holds a PhD in Communication and New Media, is a Professor of Communication in De La Salle University and Principal Investigator of Fairwork Philippines. $\bowtie$ cheryll.soriano@dlsu.edu.ph

Earvin Charles Cabalquinto is a Doctor of Philosophy and Lecturer in Communication in the School of Communication and Creative Arts at Deakin University. $\square$ earvin.cabalquinto@ deakin.edu.au

Joy Hannah Panaligan is a Master of Arts in Communication and Lecturer at the Multimedia Arts Department at De La Salle University. 


\section{References}

1. ABIDIN, Crystal. Communicative intimacies: influencers and perceived interconnectedness. Ada: A Journal of Gender, New Media \& Technology, n. 8, p. 1-16, 2015.

2. ABIDIN, Crystal. Internet celebrity: understanding fame online. Bringley: Emerald Publishing Limited, 2018.

3. AGUILAR, Filomena V. Migration revolution: Philippine nationhood and class relations in a globalized age. Quezon City: Ateneo de Manila University Press, 2014.

4. BAYM, Nancy K. Personal connections in the digital age, digital media and society series. Cambridge: Polity Press, 2010.

5. BURGESS, Jean E.; GREEN, Joshua. YouTube: online video and participatory culture. 2. ed. New York: Polity Press, 2018.

6. DE PAULA, Ana Paula P.; WOOD, Thomaz Jr. Pop-management: tales of passion, power and profit. International Journal of Organization Theory \& Behavior, $v$. 12, n. 4, p. 595-617, 2009. https://doi.org/10.1108/IJOTB-12-04-2009-B003

7. DE PEUTER, Greig; COHEN, Nicole; SARACO, Francesca. The ambivalence of coworking: on the politics of an emerging work practice. European Journal of Cultural Studies, v. 20, n. 6, p. 1-20, 2017. https://doi. org/10.1177/1367549417732997

8. DUARTE, Maria P. F. C.; MEDEIROS, Cintia R. de O. Pop-Management: 15 Years Later - the incorporation of pop-management in the work of executives of big companies. Cadernos EBAPE.BR, v. 17, n. 1, p. 185-198, 2019. https://doi. org/10.1590/1679-395169212

9. DUFFY, Brooke E. (Not) getting paid to do what you love: gender, social media, and aspirational work. New Haven: Yale University Press, 2017.

10. EADIE, Pauline. Typhoon Yolanda and post-disaster resilience: Problems and challenges. Asia Pacific Viewpoint, v. 60, n. 1, p. 94-107, 2019. https://doi. org/10.1111/apv.12215

11. FRANCISCO-MENCHAVEZ, Valerie. The labor of care: Filipina migrants and transnational families in the digital age. Urbana: University of Illinois Press, 2018.

12. GARCÍA-RAPP, Florencia. Popularity markers on YouTube's attention economy: the case of Bubzbeauty. Celebrity Studies, v. 8, n. 2, p. 228-245, 2017. https:// doi.org/10.1080/19392397.2016.1242430

13. GILL, Rosalind; PRAT, Andy. In the social factory? Immaterial labour, precariousness and cultural work. Theory, Culture \& Society, v. 25, n. 7-8, p. 1-30, 2008. https://doi.org/10.1177/0263276408097794

14. GRAHAM, Mark; ANWAR, Mohammad A. The global gig economy: towards a planetary labour market? First Monday, v. 24, n. 4, 2019. https://doi.org/10.5210/ $\underline{\text { fm.v24i4.9913 }}$ 
15. GRAHAM, Mark; HJORTH, Isis; LEHDONVIRTA, Vili. Digital labour and development: impacts of global digital labour platforms and the gig economy on worker livelihoods. Transfer: European Review of Labour and Research, v. 23, n. 2, p. 135-162, 2017. https://doi.org/10.1177/1024258916687250

16. GRAHAM, Mark; LEHDONVIRTA, Vili.; WOOD, Alex; BARNARD, Helena; HJORTH, Isis; SIMON, David P. The risks and rewards of online gig work at the global margins. Oxford Internet Institute, 2017. Available at: https://www.oii. ox.ac.uk/publications/gigwork.pdf

17. HESMONDHALGH, David; BAKER, Sarah. A very complicated version of freedom: conditions and experiences of creative labour in three cultural industries. Poetics, v. 38, n. 1, p. 4-20, 2010. https://doi.org/10.1016/j.poetic.2009.10.001

18. HJORTH, Larissa. It's complicated: a case study of personalisation in an age of social and mobile media. Communication, Politics \& Culture, v. 44, n. 1, p. 4559, 2011. https://search.informit.org/doi/10.3316/informit.127649781513814

19. LANGE, Patricia G. Thanks for watching: an anthropological study of video sharing on YouTube. Louisville: University Press of Colorado, 2019.

20. LEHDONVIRTA, Vili. Algorithms that divide and unite: delocalisation, identity and collective action in microwork. In: FLECKER, Jorg (ed.). Space, place and global digital work: dynamics of virtual work. London: Palgrave, Macmillan, 2016. p. 53-80.

21. LIN, Weiqiang; LINDQUIST, Johan; XIANG, Biao; YEOH, Brenda S. A. Migration infrastructures and the production of migrant mobilities. Mobilities, $\mathrm{v}$. 12, n. 2, p. 167-174, 2017. https://doi.org/10.1080/17450101.2017.1292770

22. MARWICK, Alice E. Status update: celebrity, publicity, and branding in the social media age. New Haven: Yale University Press, 2013.

23. NEILSON, Brett; ROSSITER, Ned. Precarity as political concept, or Fordism as exception. Theory Culture and Society, v. 25, n. 7-8, p. 51-72, 2008. https://doi. org/10.1177/0263276408097796

24. PADIOS, Jan M. A nation on the line: call centers as postcolonial predicaments in the Philippines. Durham: Duke University Press, 2018.

25. PAYONEER. The global gig-economy index: cross-border freelancing trends that defined Q2 2019. Available at: https://explore.payoneer.com/q2 global freelancing index/

26. PE-PUA, Rogelia; PROTACIO-MARCELINO, Elizabeth A. Sikolohiyang Pilipino (Filipino psychology): a legacy of Virgilio G. Enriquez. Asian Journal of Social Psychology, v.3, n. 1, p. 49-71, 2000. https://doi.org/10.1111/1467-839X.00054

27. RHEINGOLD, Howard. The virtual community: homesteading on the electronic frontier. Cambridge: MIT Press, 1993.

28. RODRIGUEZ, Robyn M. Migrants for export: how the Philippine state brokers to the world. Minneapolis: The University of Minnesota Press, 2010. 
29. RUIZ, James T. Online jobs at home Philippines for beginners (Full Tutorial), 2019. Available at: https://www.youtube.com/watch?v=GU0 3FZtISA

30. SAN JUAN JUNIOR, Epifanio. The Filipino diaspora. Philippine Studies, v. 49, n. 2, p. 255-264, 2001.

31. SENFT, Theresa. Microcelebrity and the branded self. In: BURGESS, Jean Elizabeth; BRUNS, Axel (eds.). A companion to new media dynamics. Malden: Blackwell, 2013. p. 346-54.

32. SORIANO, Cheryll R. Digital Labour in the Philippines: Emerging Forms of Brokerage. Media International Australia, v. 179, n. 1, p. 23-37, 2021. Available at: https://doi.org/10.1177/1329878X21993114

33. SORIANO, Cheryll Ruth; CABANES, Jason Vincent. Entrepreneurial solidarities: Social media collectives and Filipino digital platform workers. Social Media + Society, v. 179, n. 1, p. 2-11, 2020. https://doi.org/10.1177/1329878X21993114 34. SORIANO, Cheryll R.; PANALIGAN, Joy H. Skill-makers' in the platform economy: transacting digital labor. In: ATHIQUE, Adrian; \& BAULCH, Emma. Digital transactions in Asia: Economic, informational, and social exchanges. London \& New York: Routledge, 2019. p.172-191.

35. WOOD, Thomaz Jr.; DE PAULA, Ana Paula P. Pop-management literature: popular business press and management culture in Brazil. Canadian Journal of Administrative Sciences / Revue Canadienne Des Sciences de I'Administration, v. 25, n. 3, p. 185-200, 2008. https://doi.org/10.1002/cjas.71

36. WOOD, Alex; LEHDONVIRTA, Vili; GRAHAM, Mark. Workers of the world unite? Online freelancer organisation among remote gig economy workers in six Asian and African countries. New Technology, Work and Employment, v. 33, n. 2, p. 95-112, 2018. https://doi.org/10.1111/ntwe.12112

Received 14 Apr. 2021.

Accepted 7 July 2021. 